\title{
Nailing down 'academic' freedom and tenure in Greek research institutions
}

\author{
Konstantinos I. Stergiou ${ }^{1,2, *}$, Athanassios Machias ${ }^{1}$ \\ ${ }^{1}$ Institute of Marine Biological Resources and Inland Waters, Hellenic Centre for Marine Research, Aghios Kosmas, \\ 16777 Athens, Greece \\ ${ }^{2}$ Laboratory of Ichthyology, Department of Zoology, School of Biology, Aristotle University of Thessaloniki, UP Box 134, \\ 54124 Thessaloniki, Greece
}

\begin{abstract}
In this essay we describe the different blows that research in Greece has suffered because of the economic crisis (i.e. drastic budgetary cuts, hiring freezes for new positions, severe salary cuts, and austerity-driven brain-drain), despite the fact that Greek research is prospering in terms of publications and citations. In addition, we discuss the last blow to Greek research; notably, the abolishment of tenure and the change in the status of researchers through the new law for research passed in December 2014, and its effects on 'academic' freedom.
\end{abstract}

KEY WORDS: Tenure $\cdot$ Academic freedom $\cdot$ Research institutes $\cdot$ Greece $\cdot$ Economic crisis $\cdot$ Law for research

\section{INTRODUCTION}

Tenure in recent years has been under dispute (e.g. Kaplan 2010, Wetherbe 2013, Peterson 2014). In fact, abolishing tenure is not a surprise given the marketization of the last societal pillars, i.e. education and research (Stergiou \& Tsikliras 2014a). Stergiou \& Tsikliras (2014b) maintain that the marketization of higher education (e.g. Amsler 2014, Lynch 2014) might be related to the recent decrease in tenured positions (e.g. in the US, the combined tenured/ tenure-track rate declined from $56 \%$ in 1975 to $31.9 \%$ in 2005: https://en.wikipedia.org/wiki/Tenure), and the increase in cheaper, more flexible and less secure work contracts. Yet tenure guarantees the freedom of professors and researchers to produce and teach knowledge against prevailing orthodoxies, political and lobby landscapes and fashionable issues. Abolishing tenure strongly impinges on 'academic' freedom (see e.g. www.aaup.org/our-work/

\footnotetext{
${ }^{*}$ Corresponding author: kstergio@bio.auth.gr
}

protecting-academic-freedom; Fossey \& Wood 2004, Karran 2009, Vrielink et al. 2011, Horn 2015, Lynch \& Ivacheva 2015, Nelson 2015, Traianou 2015), which is the pillar of higher educational and research institutions. Although the concept of academic freedom typically refers to university faculty, we extent it to cover research institutions as well. In addition, we consider academic freedom to imply the 3 aspects defined by Vrielink et al. (2011, p. 117): the freedom of individuals, the autonomy of institutions and the 'obligation for the public authorities to respect and protect academic freedom and to take measures in order to ensure an effective enjoyment of this right and to promote it'.

On December 2014, during the sixth year of the economic crisis in Greece, a new law for research was passed in the Greek parliament. In this short essay, we briefly describe the effects of the economic crisis on Greek research and discuss the effects of the volte-face resulting from the new law on academic

๑ T The authors 2015. Open Access under Creative Commons by Attribution Licence. Use, distribution and reproduction are unrestricted. Authors and original publication must be credited. 
freedom through the abolishment of tenure and the change in the status of researchers; the last nail in the coffin of Greek research.

\section{GREEK ECONOMIC CRISIS AND RESEARCH}

One of the actions of the Greek government to 'tackle' the recent economic crisis was to drastically cut the funding of research centres from about 80 million euros in 2008 to less than 40 million in 2014 (EEE 2013). Yet, the memorandum signed by the government for economic support from the European Union, European Central Bank and International Monetary Fund (known as 'Troika') stated that research should be excluded from the state retrenchment. This is reasonable given the variety of economic benefits of publicly funded basic research (e.g. Salter \& Martin 2001). As Nelson \& Romer (1996, p. 9) claim: 'Encouraging R\&D investment is as important as investing itself'.

Historically, Greek research started to develop mainly within the framework of the European Economic Community (and later European Union). This is reflected in the number of Greek scientific publications (which increased exponentially from 1980 to 2008; Stergiou \& Pantis 2006, National Documentation Centre 2014), and the percentage of Greek publications compared to global publications (which increased from $0.17 \%$ between 1975 and 1980 , to $0.82 \%$ between 2003 and 2005; Stergiou \& Pantis 2006). In addition, the impact of Greek publications (i.e. the ratio of total number of citations divided by the total number of publications across all scientific disciplines) exponentially increased between 1996 and 2010 unlike that for 27 European Union countries and for the Organisation for Economic Cooperation and Development (OECD) countries, which exhibited a linear increase (Fig. 1). The rate of increase for Greece was 33 and 50\% faster than those rates of European Union and OECD countries, respectively (i.e. the linear slopes of the impact vs. time regression were $0.20,0.15$ and 0.13 , respectively) (Fig. 1). At the same time, for each euro on average invested in Greek research centers, mainly through projects funded by the European Union, 3 euros were returned back to the economy (National Documentation Centre 2013).

This progress in scientific output has also been reflected in the evaluations of Greek research institutions. Thus, the average score of the evaluation of the existing 31 Greek research institutes (belonging to 10 centres) by international committees in January 2014 (www.gsrt.gr) was 4.38 out of 5 ( $\mathrm{SE}=0.49$, median $=4.51)($ EEE 2014) .

These above-mentioned facts show that Greek research is export-oriented, prospering and competitive in the international research landscape. Yet, this is realized in a politically, socially and economically negative national landscape, which is the result of various factors acting together. Firstly, there is a devaluation of the research (and university) role by the national media (Stergiou \& Tsikliras 2012). Secondly, there is the burden of bureaucracy, which was, and still is, a serious problem in Greece (Spanou 2008, Danopoulos \& Danopoulos 2009). It is much higher in Greece and other southern European countries compared to the remaining EU countries (e.g. Van De Walle 2006, EconMatters 2011), and has a

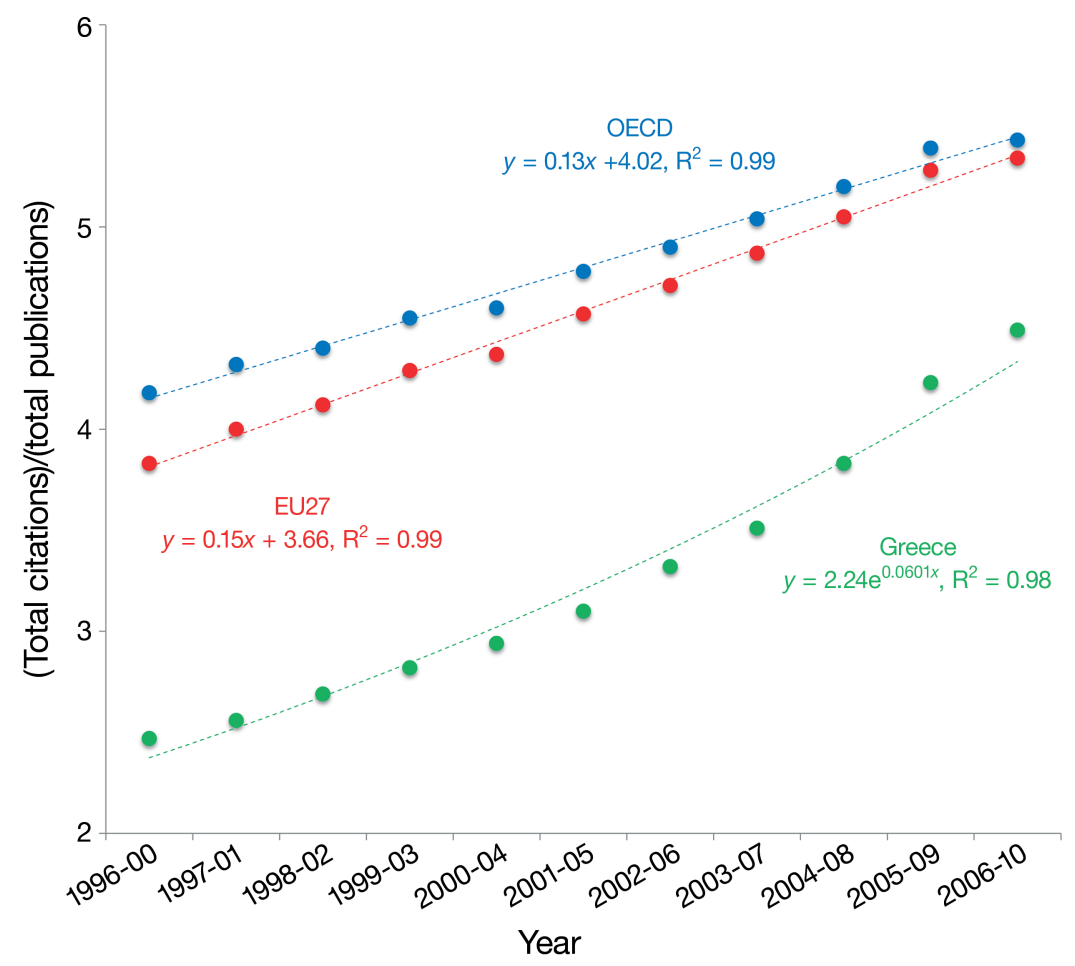

Fig. 1. Impact of publications (i.e. total number of citations divided by total number of publications for all disciplines) in Greece, in 27 countries of the European Union (EU27) and in the countries of the Organisation for Economic Co-operation and Development (OECD). Data were taken from the National Documentation Centre (2014), and a time varying regression was fitted 
negative impact on the country's economic growth (Papaconstantinou et al. 2013). Greek bureaucracy is generally inefficient and obstructionist (Danopoulos \& Danopoulos 2009). In fact, the 'Napoleonic' aspects of Greek bureaucracy have never been thoroughly reformed based on modern managerial practices, and the various reform attempts that have been implemented were often contradictory (Spanou 2008). More importantly, Greek bureaucracy has no autonomy from the state and the political parties, and lacks a universalistic approach (Papakostas 2001). It suffices to say that for several institutions recruitment of scientists and provision of key equipment through tenders is often such a time-consuming process that it negatively affects the realization of scientific projects. Finally, national research funding is very low. The analysis of EUROSTAT data shows that in 2012 Greece spent only $0.71 \%$ of its GDP on funding research, attaining the fifth lowest rank among EU countries (followed by Latvia, Romania, Malta and Bulgaria), with expenditure on research being half of the EU average (1.42\%) (Feidas 2014). In contrast, Portugal, which was also hit by an economic crisis, spent $2 \%$ of its GPD on the same and ranked fourth in the EU (after Iceland, Estonia and Germany) (Feidas 2014).

Apart from the drastic budgetary cuts that took place after 2011, new position openings for research institutes (and universities) were frozen and the salaries of professors and researchers were severely cut (Stergiou \& Tsikliras 2012) by about 30 to $40 \%$ depending on the rank (Feidas 2014). These were the first nails in the coffin of Greek research (and education), and led to austerity-driven brain-drain (Stergiou \& Tsikliras 2012, Trachana 2013).

\section{TENURE LANDSCAPE BEFORE AND AFTER DECEMBER 2014}

In November 2014, the Greek government presented for discussion in parliament the new draft law on research (and innovation). All previous laws for research (1514/1985, 3653/2008) explicitly stated that researcher positions of grade A and B (but not of grade D and C) are tenured, as is also (still) the case for university associate and full professor positions (as opposed to lecturers and assistant professors). In the draft law, reference to tenure was removed. The political leadership had several meetings with research centres and other bodies reassuring them that the removal of tenure was a 'mistake' that was to be corrected with an amendment during the discus- sion of the draft law in parliament. During the discussion period, various bodies (i.e. the union of Greek researchers, labour unions of research centres, different political parties, deputies and other political bodies) proposed numerous amendments on the draft law, including one on the reestablishment of tenure. The law $(4310 / 2014)$ was finally passed on 8 December 2014. Indeed, the 'mistake' was 'corrected', but in the wrong direction: instead of explicitly stating the symbolic word 'tenure', the corresponding sentence now mentions that researchers are 'of indefinite term' state servants 'under the code for civil servants'. This is even worse than the removal of the word 'tenure' because it implies that research staff owes loyalty to the government and not to the citizenry.

\section{POTENTIAL IMPLICATIONS}

The removal of 'tenure' and its subsequent replacement with 'state servants' in the new law of research prepares the ground for the gradual reduction in the number of tenured researchers and their replacement in favour of cheap labour on a contract basis. It also allows the state to actually prevent researchers from speaking up, especially for a series of hot issues related to topics such as the environment, climate change, physical disasters, socio-economics and fisheries. This was the case in Canada after the conservative government came into power in 2006, for several environmental issues (see Pauly 2015, this Theme Section). The change from 'tenure' to 'state servants' will have long-term effects on the Greek research system, since it will transform researchers from independent experts to government servants. Thus, the new law could potentially affect all 3 aspects of academic freedom as defined by Vrielink et al. (2011) (see 'Introduction').

Nonetheless, other underlying reasons (e.g. related to lobbying) might also be behind this law-imposed dismissal of tenure (as opposed to dismissal for cause, e.g. neglect of duty, misconduct). In any case, this last nail in the coffin of Greek research will undoubtedly have wider repercussions on the future economic development of Greece, given that academic freedom is the ticket for future economic growth. This is because academic freedom contributes greatly to the shift from maintenance learning to dynamic learning, with the latter defined as 'problem reformulation and novel thinking to facilitate knowledge creation' (Karran 2009, p. 278). Dynamic learning asks for a continuous questioning of the status quo and ensures that 
young scientists will develop '... independent thinking and critical reasoning, and thereby better fulfil their responsibilities as active, participative citizens within an increasingly global community' (Karran 2009, p. 278).

In general, although the Greek state has the recognized 'brain drain' triggered by the economic crisis as one of the biggest socio-economic problems, it has never considered research as the 'cheap' and best investment for future growth. This is elegantly expressed by the saying attributed to the Greek researcher Giorgos Papanicolaou, the inventor of the Pap test: ' ... If I come to Greece I fear that I will be committing suicide. Americans and Europeans consider scientists as valuable members of the society, whereas Greeks treat scientists as obsolete and burden and in some instances even dangerous...' Hopefully, this attitude and the implicit 'mistake' in the Greek legislation framework for research will, soon, be reversed.

Acknowledgements. The authors thank Drs. A. Magoulas and S. Somarakis, as well as 3 anonymous reviewers, for useful comments and suggestions.

\section{LITERATURE CITED}

Amsler S (2014) University ranking: a dialogue on turning towards alternatives. Ethics Sci Environ Polit 13:155-166

Danopoulos CP, Danopoulos AC (2009) Greek bureaucracy and public administration: the persistent failure of public reform. In: Farazmand A (ed) Bureaucracy and administration. CRC Press, Boca Raton, FL, p 395-408

EconMatters (2011) Comparing bureaucracy: no wonder the euro zone is in crisis. EconMatters, 11 Dec 2011. www. econmatters.com/2011/12/comparing-bureaucracy-nowonder-euro.html (accessed 8 Mar 2015)

EEE (2013) Open letter to Prime Minister. Union of Greek Researchers. http://eee-researchers.gr/Anakoinoseis-EEE/ EEE_EX_452_Anoikti-Epistoli-Prothupourgos_01-11-2013. (accessed 8 Mar 2014) (in Greek)

EEE (2014) Open letter to Prime Minister. Union of Greek Researchers. http://eee-researchers.gr/Anakoinoseis-EEE/ EEE_EX_459_Anoikti-Epistoli-Prothupourgos_08-04-2014. pdf (accessed 8 Mar 2014) (in Greek)

Feidas C (2014) The state of the salaries of Greek university professors. Thessaloniki. www.esos.gr/sites/default/files/ articles-legacy/meleti_misthologika_panipistimiakon_ 2014.pdf (accessed 10 Sep 2015) (in Greek)

Fossey R, Wood RC (2004) Academic freedom and tenure. New Directions for Community Colleges (Spec Issue) 2004:51-63

Horn M (2015) Tenure and academic freedom in Canada. Ethics Sci Environ Polit 15:23-37

Kaplan K (2010) The changing face of tenure. Nature 468: $123-125$

Karran T (2009) Academic freedom: in justification of a uni-

Editorial responsibility: Stylianos Somarakis,

Heraklion, Greece versal ideal. Stud High Educ 34:263-283

Lynch K (2014) New managerialism, neoliberalism and ranking. Ethics Sci Environ Polit 13:141-153

Lynch K, Ivancheva M (2015) Academic freedom and the commercialisation of universities: a critical ethical analysis. Ethics Sci Environ Polit 15:71-85

National Documentation Centre (2013) Research and development indices for expenditure and personnel in Greece. http://metrics.ekt.gr/el/node/108 (in Greek)

National Documentation Centre (2014) Research and development indices for Greek expenses 2013. http://metrics. ekt.gr/el/node/173 (in Greek)

Nelson C (2015) Dystopia is now: the threats to academic freedom. Ethics Sci Environ Polit 15:17-22

Nelson RR, Romer PM (1996) Science, economic growth, and public policy. Challenge (White Plains) 39:9-21

Papaconstantinou P, Tsagkanos AG, Siriopoulos C (2013) How bureaucracy and corruption affect economic growth and convergence in the European Union: the case of Greece. Managerial Finance 39:837-847

Papakostas A (2001) Why is there no clientelism in Scandinavia? A comparison of the Swedish and Greek sequences of development. In: Piattoni S (ed) Clientelism, interests, and democratic representation: the European experience in historical and comparative perspective. Cambridge University Press, Cambridge, p 31-53

Pauly D (2015) Tenure, the Canadian tar sands and 'Ethical Oil'. Ethics Sci Environ Polit 15:55-57

Peterson PE (2014) The public turns against teacher tenure. Wall St J, 19 Aug 2014. www.wsj.com/articles/paul-epeterson-the-public-turns-against-teacher-tenure-14084 20803 (assessed 15 Jun 2015)

Salter AJ, Martin BR (2001) The economic benefits of publicly funded basic research: a critical review. Res Policy 30:509-532

Spanou C (2008) State reform in Greece: responding to old and new challenges. Int J Public Sector Management 21: 150-173

Stergiou KI, Pantis I (2006) University research and evaluation. Panepistimioupoli 2006:8-9 (in Greek)

Stergiou KI, Tsikliras AC (2012) Europe's economic crisis hits Greek universities hard. Chronicles of Higher Education. http://chronicle.com/article/Europes- EconomicCrisis-Hits/134814/

Stergiou KI, Tsikliras AC (2014a) Global university reputation and rankings: insights from culturomics. Ethics Sci Environ Polit 13:193-202

Stergiou KI, Tsikliras AC (2014b) Global university rankings uncovered: introduction. Ethics Sci Environ Polit 13: 59-64

- Trachana V (2013) Austerity-led brain drain is killing Greek science. Nature 496:271

> Traianou A (2015) The erosion of academic freedom in UK higher education. Ethics Sci Environ Polit 15:39-47

Van De Walle S (2006) The state of the world's bureaucracies. J Comp Policy Anal 8:437-448

Vrielink J, Lemmens P, Parmentier S, the LERU Working Group on Human Rights (2011) Academic freedom as a fundamental right. Procedia Soc Behav Sci 13:117-141

Wetherbe JC (2013) It's time for tenure to lose tenure. Harvard Business Review, 13 Mar 2013. https://hbr.org/ 2013/03/its-time-for-tenure-to-lose-te/ (accessed 8 Mar 2015)

Submitted: March 18, 2015; Accepted: July 8, 2015

Proofs received from author(s): September 10, 2015 